\title{
Response of Container-grown Confetti Tree Irrigated with Runoff Water
}

\author{
Pedro García-Caparrós ${ }^{1}$, Alfonso Llanderal ${ }^{1}$, Ahmed El-Tarawy², \\ John Majsztrik ${ }^{3}$, and María Teresa Lao ${ }^{1,4}$
}

AdDITIONAL INDEX WORDs. Maytenus senegalensis, ornamental plants, reuse water, Ruscus aculeatus, salt ions

Summary. This experiment measured plant growth of a halophyte (species adapted to saline conditions) confetti tree (Maytenus senegalensis) using runoff from kneeholy plants (Ruscus aculeatus). Three irrigation treatments were used, a standard nutrient solution or control $\left(T_{0}\right)$, runoff water collected from kneeholy plants irrigated with the standard nutrient solution blended 50:50 with tap water $\left(T_{1}\right)$, and $100 \%$ runoff water collected from kneeholy plants irrigated with the standard nutrient solution $\left(T_{2}\right)$, in which the nutrient concentrations were analyzed by highperformance liquid chromatography. Growth, photosynthetic parameters, and mineral composition were measured at the end of the experiment. Electrical conductivity and $\mathrm{pH}$ increased with increasing runoff application (decreased blending). Treatment 2 had significantly higher plant height, number of branches, number of leaves, leaf area index, and dry weight. Treatments 1 and 2 had significantly lower root lengths compared with the control. Chlorophyll concentration and green index color in leaves were greater in $T_{2}$ and $T_{1}$ than $T_{0}$. The mineral composition of roots and leaves was affected by irrigation treatment, resulting in an increase of sodium and chloride concentration and a decline of nitrogen and phosphorous concentration compared with the control. The reuse of runoff water was beneficial for growing this commercially important halophytic species in Spain, a consideration that is particularly relevant in locations with water quality, quantity issues, or both.

$\mathrm{O}$ rnamental greenhouse-grown plants are typically grown with either controlled-release fertilizer or fertigation, with typical nitrogen $(\mathrm{N})$ rates of $50-300 \mathrm{mg} \cdot \mathrm{L}^{-1}$, which may be applied multiple times per day because of container volume limitations and substrate water-holding properties. This can lead to fertilizer leaching and runoff, and contamination of ground and surface waters from $\mathrm{N}$ and phosphorus (P) in runoff water (Narváez et al., 2011).

Global concerns about water quality and quantity, as well as environmental regulations, which aim to reduce nutrient leaching into surface and groundwater, have prompted a number of research efforts including the evaluation of alternative irrigation for agriculture (Jarecki et al., 2005;

${ }^{1}$ Department of Agronomy, Higher Polytechnic School and Experimental Science College, University of Almeria, Agrifood Campus of International Excellence ceiA3. Ctra. Sacramento s/n, La Cañada de San Urbano, 04120, Almería, Spain

${ }^{2}$ Faculty of Agriculture, Kafrelsheikh University, Kafr El-Shaikh, Egypt

${ }^{3}$ Department of Plant and Environmental Sciences, Clemson University, Clemson, SC 29634

${ }^{4}$ Corresponding author. E-mail: mtlao@ual.es.

doi: 10.21273/HORTTECH03779-17
Purvis et al., 2000). One option for alternative water supply is the sequential reuse of runoff water to irrigate increasingly salt-tolerant plants $\mathrm{Su}$ et al., 2005). In this system, the runoff water collected from one crop is used to irrigate a more salt-tolerant crop. It is vitally important that each subsequent crop is able to tolerate the accumulated salts to avoid crop damage and death (Grattan et al., 2011).

The Mediterranean region is characterized by an annual average rainfall of $50 \mathrm{~cm}$, which can lead to poor irrigation water quality because of increased salt concentrations during the dry season (Rana and Katerji, 2000). The use of native Mediterranean species in xeriscaping, landscaping, and revegetation projects has increased in recent years because of their adaptability under varying environmental conditions (Álvarez et al., 2012). Among these Mediterranean species, kneeholy and confetti tree are widely grown for their commercial value (Lopez, 2004; Veronese, 2014). Although there are a number of publications that have investigated the reuse of runoff water in nursery production (Owen et al., 2008; Polomski et al., 2005, 2008), little is known about reusing irrigation water for the production of confetti tree. A greenhouse experiment was conducted to determine the effects of different irrigation treatments on biomass, mineral composition, and photosynthetic parameters of this species.

\section{Materials and methods}

Plant material and cultural CONDITIONS. The experiment was carried out at the University of Almeria, Spain (lat. $36^{\circ} 49^{\prime} \mathrm{N}$, long. $2^{\circ} 24^{\prime} \mathrm{W}$ ). Rooted 0.2 -L plugs of kneeholy and confetti tree were obtained from a local nursery. Both species were transplanted into 1.5-L polyethylene containers (one plant per container) containing a substrate of peatmoss and perlite 80:20 (by volume) (Projar Professional CPl + Perlite; Projar, Sao Paulo, Brazil), without any additional amendments. The experimental period was 8 weeks to reflect typical production time in the region (11 Feb. to 5 Apr. 2013). The microclimatic conditions inside the greenhouse for the study were monitored continuously with data loggers (HOBO SHUTTLE model H 08004-02; Onset Computer Corp., Bourne, MA). Daily average temperature during the study was $17^{\circ} \mathrm{C}$, relative humidity was $66 \%$, and photosynthetically active radiation $(P A R)$

\begin{tabular}{|c|c|c|c|}
\hline $\begin{array}{l}\text { Units } \\
\text { To convert U.S. to SI, } \\
\text { multiply by }\end{array}$ & U.S. unit & SI unit & $\begin{array}{l}\text { To convert SI to U.S., } \\
\text { multiply by }\end{array}$ \\
\hline 29.5735 & $\mathrm{floz}$ & $\mathrm{mL}$ & 0.0338 \\
\hline 0.0929 & $\mathrm{ft}^{2}$ & $\mathrm{~m}^{2}$ & 10.7639 \\
\hline 3.7854 & gal & $\mathrm{L}$ & 0.2642 \\
\hline 2.54 & inch(es) & $\mathrm{cm}$ & 0.3937 \\
\hline 1 & $\operatorname{micron}(\mathrm{s})$ & $\mu \mathrm{m}$ & 1 \\
\hline 1,000 & $\mathrm{mmho} \cdot \mathrm{cm}^{-1}$ & $\mu \mathrm{S} \cdot \mathrm{cm}^{-1}$ & 0.0010 \\
\hline 1 & $\mathrm{mmho} \cdot \mathrm{cm}^{-1}$ & $\mathrm{~d} S \cdot \mathrm{m}^{-1}$ & 1 \\
\hline 28.3495 & $\mathrm{oz}$ & g & 0.0353 \\
\hline 0.001 & $\mathrm{ppm}$ & $\mathrm{mg} \cdot \mathrm{g}^{-1}$ & 1,000 \\
\hline 1 & $\mathrm{ppm}$ & $\mathrm{mg} \cdot \mathrm{L}^{-1}$ & 1 \\
\hline$\left({ }^{\circ} \mathrm{F}-32\right) \div 1.8$ & ${ }^{\circ} \mathrm{F}$ & ${ }^{\circ} \mathrm{C}$ & $\left({ }^{\circ} \mathrm{C} \times 1.8\right)+32$ \\
\hline
\end{tabular}


was $6 \mathrm{~mol} \cdot \mathrm{m}^{-2} \cdot \mathrm{d}^{-1}$. The $P A R$ was measured by a quantum sensor (model QSO-SUN; Apogee Instruments, Logan, UT) placed in the plant canopy and connected to a data logger. Data were collected at 5-min intervals and the average $P A R$ for a 24-h period was recorded.

EXPERIMENTAL DESIGN AND TREATMENTS. The experiment consisted of three irrigation treatments for the production of confetti tree. $\mathrm{T}_{0}$ which was standard nutrient solution reported by Jimenez and Caballero (1990) consisting of tap water [64 mg. $\mathrm{L}^{-1}$ sulfur $(\mathrm{S}), 122 \mathrm{mg} \cdot \mathrm{L}^{-1}$ chloride $\left(\mathrm{Cl}^{-}\right), 80 \mathrm{mg} \cdot \mathrm{L}^{-1}$ calcium $\left(\mathrm{Ca}^{2+}\right), 34 \mathrm{mg} \cdot \mathrm{L}^{-1}$ magnesium $\left(\mathrm{Mg}^{2+}\right)$, and $60 \mathrm{mg} \cdot \mathrm{L}^{-1}$ sodium $\left(\mathrm{Na}^{+}\right)$; electical conductivity (EC) of $0.9 \mathrm{dS} \cdot \mathrm{m}^{-1}$ ] with phosphoric acid $\left(\mathrm{H}_{3} \mathrm{PO}_{4}\right)$, nitric acid $\left(\mathrm{HNO}_{3}\right)$, potassium nitrate $\left(\mathrm{KNO}_{3}\right)$, and calcium nitrate $\left[\mathrm{Ca}\left(\mathrm{NO}_{3}\right)_{2} \mathrm{H}_{2} \mathrm{O}\right]$ at $67.9,117,300$, and $109 \mathrm{mg} \cdot \mathrm{L}^{-1}$, respectively $\left[84,22\right.$, and $117 \mathrm{mg} \cdot \mathrm{L}^{-1}$ of $\mathrm{N}, \mathrm{P}$, and potassium $(\mathrm{K})$, respectively]; $\mathrm{T}_{1}$ which was runoff water (collected from kneeholy plants irrigated with the standard nutrient solution) blended 50:50 with tap water; and $\mathrm{T}_{2}$ which was $100 \%$ runoff water (collected from kneeholy plants irrigated with the standard nutrient solution) (Table $\mathrm{l}$ ).

Runoff from each kneeholy container was collected by placing a tightfitting plastic collection container under each plant. Plant containers were elevated to prevent leachate from being reabsorbed into the container. Samples were manually collected each week and stored in black plastic bottles. Confetti tree plants were hand watered daily with $70 \mathrm{~mL}$ of their irrigation treatment during the experimental growing period. The experimental design consisted of three irrigation treatments, four blocks, and four plants (one plant per container) per block giving a total of 48 plants plus border plants.

Growth parameters. At the end of the experiment, four plants per treatment were randomly selected to determine growth parameters.
Plant height from the top edge of the container to the last open leaf of the plant crown was measured. Branch and leaf number of each plant were counted directly on intact plants. Leaf area index (LAI) was determined from digitized images of each plant using the Idrisi Selva computer program (Clark Laboratories, Worcester, MA) as reported by Vaesen et al. (2001). Plants were then harvested, the substrate gently washed from the roots with tap water and then rinsed twice with deionized water and the root surface dried with blotting paper. The longest root length was then measured from the crown to the tip of the root. Plants were divided into roots, stems, and leaves to determine the fresh weight (FW) of each organ. These organs were then ovendried at $60{ }^{\circ} \mathrm{C}$ until they reached a constant weight. Plant dry weight (DW) was calculated as the sum of the root, stem, and leaf DW.

COLOR PARAMETERS AND PHOTOSYNTHETIC PIGMENTS IN LEAVES. Before the initiation of the treatments and at the end of the experiment, four plants per treatment were randomly selected to determine the color index in the leaves for red $(\mathrm{R})$, green $(\mathrm{G})$, and blue (B) pigments as per Ali et al. (2012). Briefly, the RGB values were analyzed using an optical scanner (ES-2000; Seiko Epson Corp., Suwa, Japan) and the images were processed with Adobe Photoshop CS6 (Adobe System Software, Dublin, Ireland) by averaging the $R, G$, and $B$ values of all the leaf pixels. The same plants randomly designated for the determination of color index in leaves were also used to determine the photosynthetic pigments concentration. Extraction of chlorophyll $a$ and $b$ (Chl $a$ and $\mathrm{Chl} b$ ) and carotenoids were performed by submerging $0.2 \mathrm{~g}$ of fresh leaves in methanol in the dark at room temperature $\left(15^{\circ} \mathrm{C}\right)$ for $24 \mathrm{~h}$. The supernatant was removed and the photosynthetic pigment concentrations were determined colorimetrically at their respective

Table 1. Description of the three irrigation treatments of confetti tree grown in 1.5-L (0.40 gal) containers containing peatmoss and perlite 80:20 (by volume).

\begin{tabular}{lccc}
\hline Treatment & Nutrient solution $(\mathrm{mL})^{\mathbf{z}}$ & Runoff water $(\mathrm{mL})$ & Tap water $(\mathbf{m L})$ \\
\hline $\mathrm{T}_{0}$ & 70 & 0 & 0 \\
$\mathrm{~T}_{1}$ & 0 & 35 & 35 \\
$\mathrm{~T}_{2}$ & 0 & 70 & 0 \\
\hline
\end{tabular}

${ }^{\mathrm{z}} 1 \mathrm{~mL}=0.0338 \mathrm{fl} \mathrm{oz}$. wavelengths in a spectrophotometer (ultraviolet-1201; Shimadzu Scientific Instruments, Columbia, MD): Chl $a(\lambda=666 \mathrm{~nm})$, Chl $b(\lambda=653 \mathrm{~nm})$, and carotenoids $(\lambda=470 \mathrm{~nm})$ following the methodology of Wellburn (1994).

Mineral composition. Ovendried samples of roots, stems, and leaves were milled (Grindomix GM 200; Retsch, Haan, Germany), cleaning the mill between samples. Each sample was divided into two subsamples. One subsample was used to analyze chloride and nitrate $\left(\mathrm{NO}_{3}\right)$ concentration using water extraction and high-performance liquid chromatography as described by Csáky and Martínez-Grau (1998). The other subsamples were mineralized with 96\% sulphuric acid $\left(\mathrm{H}_{2} \mathrm{SO}_{4}\right)$ in the presence of $\mathrm{P}$-free hydrogen peroxide $\left[\mathrm{H}_{2} \mathrm{O}_{2}, 30 \%(\mathrm{w} / \mathrm{v})\right]$ at $300{ }^{\circ} \mathrm{C}$ and used for the determination of organic N (Krom, 1980), total P (Hogue et al., 1970), $\mathrm{K}^{+}$, and $\mathrm{Ca}^{2+}$ (Lachica et al., 1973) concentrations. Total N concentration was calculated as the sum of the organic $\mathrm{N}$ and $\mathrm{NO}_{3}{ }^{-}$ concentration.

Nutrient solution anALYsis. Four runoff samples per treatment were collected weekly. At the time of collection, $\mathrm{EC}$ and $\mathrm{pH}$ values were measured (models C66 and pH52, respectively; Milwaukee Instruments, Rocky Mount, NC). For each sample, $25 \mathrm{~mL}$ was filtered through a $0.45-\mu \mathrm{m}$ membrane filter and frozen at $0{ }^{\circ} \mathrm{C}$ until nutrient analyses were conducted. Nutrient concentrations were analyzed by liquid chromatography [883 Basic IC Plus with Metrosep A SUPP 4 (anion exchange column) or Metrosep C4 100 (cation exchange column), and IC conductivity detector range of $0-15,000 \mu \mathrm{S} \cdot \mathrm{cm}^{-1}$ (Metrohm, Herisau, Switzerland)] as described by Csáky and MartínezGrau (1998) for nitrate $\left(\mathrm{NO}_{3}{ }^{-}\right)$, phosphate $\left(\mathrm{H}_{2} \mathrm{PO}_{4}^{-}\right), \mathrm{Cl}^{-}$, sulphate $\left(\mathrm{SO}_{4}{ }^{2-}\right)$, $\mathrm{Ca}^{2+}, \mathrm{Mg}^{2+}, \mathrm{K}^{+}$, and $\mathrm{Na}^{+}$(milligrams per liter).

Statistical analysis. The experiment was a completely randomized block design and the values obtained for each plant and each variable were considered as independent replicates. The analysis of variance (ANOVA) and the least significant difference (LSD) tests $(P<0.05)$ were used to assess the differences between treatments. All statistical analyses were performed using Statgraphics 
Plus for Windows (version 5.1; Statpoint Technologies, Warrenton, VA).

\section{Results and discussion}

Growth PARAmeters. Treatment 2 showed significantly higher values for plant height, number of branches, leaf number, LAI, and DW, whereas root length was significantly higher for $\mathrm{T}_{0}$ (Table 2 ). Irrigation with $\mathrm{T}_{2}$ resulted in increased growth parameters of confetti tree. itive because salt stress typically decreases plant growth (Cassaniti et al., 2009), but the selected species is halophytic (Lopez, 2004). The increase of growth parameters with the highest EC water could have been due to the species salt tolerance. Similar results were reported in other ornamental plant species, where an EC increase because of the recirculation of nutrients in the irrigation water led to increased growth. Mayotte et al. (1996) reported higher values of growth parameters such as plant height, leaves number, LAI, and dry weight of five containerized herbaceous perennial species grown with These results may seem counterintu-

recirculated nutrients without additional nutrient supplies. Purvis et al. (2000) also reported increased growth and dry weight of ninebark (Physocarpus opulifolius), whereas Chong et al. 2004) showed similar results for six species of ornamental plants, using nutrient recirculating systems. The increased growth with $\mathrm{T}_{2}$ obtained in our experiment also could have been due to the high $\mathrm{P}$ concentration in the nutrient solution or from root exudates, which may solubilize mineral and organic nutrients (Graham, 1998). Increased root length in plants irrigated with $\mathrm{T}_{0}$ could have been due to the increase in nutrients and increase in growth as reported by Mengel and Kirkby (2001).

COLOR PARAMETERS AND PHOTOSYNTHETIC PIGMENTS CONCENTRATIONS IN LEAVES. An initial harvest at the beginning of the experiment gave an average RGB of 86.16 , 105.23, and 40.36, respectively for $R, G$, and $B$ and concentrations of Chl $a\left(0.84 \mathrm{mg} \cdot \mathrm{g}^{-1} \mathrm{FW}\right), \mathrm{Chl}$ $b \quad\left(0.52 \mathrm{mg} \cdot \mathrm{g}^{-1} \mathrm{FW}\right)$, carotenoids $\left(0.30 \mathrm{mg} \cdot \mathrm{g}^{-1} \mathrm{FW}\right)$, Chl $a+b(1.35$ $\left.\mathrm{mg} \cdot \mathrm{g}^{-1} \mathrm{FW}\right)$, and a Chl $a / b$ ratio of

Table 2. Mean plant height, root length, branch and leaf number, leaf area index (LAI), and dry weight (DW) of confetti tree grown in $1.5-\mathrm{L}(0.40 \mathrm{gal})$ containers containing peatmoss and perlite 80:20 (by volume). Treatments consisted of a standard nutrient solution $\left(\mathrm{T}_{0}\right)$, runoff water collected from kneeholy plants irrigated with the standard nutrient solution blended 50:50 with tap water $\left(T_{1}\right)$, and $100 \%$ runoff water collected from kneeholy plants irrigated with the standard nutrient solution $\left(\mathrm{T}_{2}\right)$.

\begin{tabular}{lcccccr}
\hline & \multicolumn{5}{c}{ Growth parameters } \\
\cline { 2 - 6 } Irrigation & $\begin{array}{c}\text { Plant ht } \\
(\mathbf{c m})^{\mathbf{z}}\end{array}$ & $\begin{array}{c}\text { Root length } \\
(\mathbf{c m})\end{array}$ & $\begin{array}{c}\text { Branches } \\
(\text { no. })\end{array}$ & $\begin{array}{c}\text { Leaves } \\
(\text { no. })\end{array}$ & $\begin{array}{c}\text { LAI } \\
\left(\mathbf{m}^{2} \cdot \mathbf{m}^{-2}\right)^{\mathbf{z}}\end{array}$ & $\mathbf{D W}(\mathbf{g})^{\mathbf{z}}$ \\
\hline $\mathrm{T}_{0}$ & $58.7 \mathrm{~b}^{\mathrm{y}}$ & $31.3 \mathrm{a}$ & $8.0 \mathrm{~b}$ & $171.0 \mathrm{~b}$ & $1.5 \mathrm{~b}$ & $9.7 \mathrm{~b}$ \\
$\mathrm{~T}_{1}$ & $55.0 \mathrm{~b}$ & $24.2 \mathrm{~b}$ & $8.2 \mathrm{~b}$ & $173.3 \mathrm{~b}$ & $1.5 \mathrm{~b}$ & $10.1 \mathrm{~b}$ \\
$\mathrm{~T}_{2}$ & $63.2 \mathrm{a}$ & $23.8 \mathrm{~b}$ & $10.8 \mathrm{a}$ & $194.7 \mathrm{a}$ & $1.9 \mathrm{a}$ & $13.7 \mathrm{a}$ \\
\hline
\end{tabular}

${ }^{\mathrm{z}} 1 \mathrm{~cm}=0.3937$ inch, $1 \mathrm{~m}^{2}=10.7639 \mathrm{ft}^{2}, 1 \mathrm{~g}=0.0353 \mathrm{oz}$.

${ }^{\mathrm{y}}$ Means within a column with the same lowercase letter are not significantly different at $P<0.05$ (analysis of variance and least significant difference test).
1.66. During the experiment, no chlorosis or necrosis was observed in any treatment. Both $\mathrm{T}_{1}$ and $\mathrm{T}_{2}$ had significantly higher values for green color and chlorophyll concentrations (Table 3). Blue value and ratio $\mathrm{Chl} a / b$ were significantly higher $(P<0.05)$ in the $\mathrm{T}_{0}$ treatment. No significant differences were found in the color index for red and carotenoids concentrations between treatments.

Both $T_{1}$ and $T_{2}$ showed higher green index values and higher chlorophyll concentrations compared with $\mathrm{T}_{0}$. These results could be due to an increase in chlorophyll formation in $T_{1}$ and $T_{2}$ due to the increase of magnesium concentrations in the irrigation treatments as suggested by Rengel (1999). The increase of chlorophyll concentrations and green index color in leaves showed a positive correlation with Chl $a\left(R^{2}=0.75\right)$, Chl $b\left(R^{2}=0.84\right)$, and Chl $a+b\left(R^{2}=\right.$ 0.81 ) (data not shown). Similar coefficients were obtained by $\mathrm{Hu}$ et al. (2013) where leaf chlorophyll content was well correlated with image color analysis in rice (Oryza sativa). Similarly, Gómez-Bellot et al. (2014) reported an increase in leaf chlorophyll concentration ( $a, b$, and total) in dwarf japanese euonymus (Euonymus japonicus) under reclaimed wastewater irrigation with an EC of $4 \mathrm{dS} \cdot \mathrm{m}^{-1}$. It should be noted that the irrigation water used for this experiment and Gómez-Bellot et al. (2014) varied significantly. The values of EC and $\mathrm{Na}$ and $\mathrm{Ca}$ concentrations in our experiment were lower.

Plant mineral composition. Nitrogen and $P$ uptake were significantly lower $(P<0.05)$ in roots and leaves for $\mathrm{T}_{1}$ and $\mathrm{T}_{2}$, compared with $\mathrm{T}_{0}$ (Table 4 ). Potassium and Ca concentrations were not significantly different in roots, stems, and leaves

Table 3. Mean color index in leaves [ $(\operatorname{red}(\mathrm{R})$, green $(\mathrm{G})$, blue $(\mathrm{B})$ values)] and photosynthetic pigments [chlorophyll (Chl) and carotenoids] concentrations of confetti tree grown in 1.5- $\mathrm{L}(0.40 \mathrm{gal})$ containers containing peatmoss and perlite 80:20 (by volume). Treatments consisted of a standard nutrient solution $\left(\mathrm{T}_{0}\right)$, runoff water collected from kneeholy plants irrigated with the standard nutrient solution blended 50:50 with tap water $\left(T_{1}\right)$, and $100 \%$ runoff water collected from kneeholy plants irrigated with the standard nutrient solution $\left(\mathrm{T}_{2}\right)$.

\begin{tabular}{|c|c|c|c|c|c|c|c|c|}
\hline \multirow{3}{*}{$\begin{array}{l}\text { Irrigation } \\
\text { treatments }\end{array}$} & \multicolumn{6}{|c|}{ Parameters } & \multirow[b]{3}{*}{ Chl $a / b$ (ratio) } & \multirow{3}{*}{$\begin{array}{c}\mathrm{Chl} a+b \\
\left(\mathrm{mg} \cdot \mathrm{g}^{-1} \mathrm{FW}\right)\end{array}$} \\
\hline & \multicolumn{3}{|c|}{ Color } & \multirow{2}{*}{$\begin{array}{c}\mathrm{Chl} a \\
\left(\mathrm{mg} \cdot \mathrm{g}^{-1} \mathrm{FW}\right)^{\mathrm{z}}\end{array}$} & \multirow{2}{*}{$\begin{array}{c}\mathrm{Chl} b \\
\left(\mathrm{mg} \cdot \mathrm{g}^{-1} \mathrm{FW}\right)\end{array}$} & \multirow{2}{*}{$\begin{array}{c}\text { Carotenoids } \\
\left(\mathrm{mg} \cdot \mathrm{g}^{-1} \mathrm{FW}\right)\end{array}$} & & \\
\hline & $\mathbf{R}$ & $\mathbf{G}$ & B & & & & & \\
\hline $\mathrm{T}_{1}$ & $90.4 \mathrm{a}$ & $119.0 \mathrm{a}$ & $36.9 \mathrm{~b}$ & $0.82 \mathrm{a}$ & $0.49 \mathrm{a}$ & $0.29 \mathrm{a}$ & $1.65 \mathrm{~b}$ & $1.31 \mathrm{a}$ \\
\hline $\mathrm{T}_{2}$ & $90.1 \mathrm{a}$ & $120.7 \mathrm{a}$ & $36.8 \mathrm{~b}$ & $0.83 \mathrm{a}$ & $0.48 \mathrm{a}$ & $0.30 \mathrm{a}$ & $1.67 \mathrm{~b}$ & $1.29 \mathrm{a}$ \\
\hline
\end{tabular}

${ }^{\mathrm{z}} \mathrm{l} \mathrm{mg} \cdot \mathrm{g}^{-1}=1000 \mathrm{ppm}$.

${ }^{\mathrm{y}}$ Means within a column with the same letter are not significantly different at $P<0.05$ (analysis of variance and least significant difference test). 
between treatments. Declines in $\mathrm{N}$ and $\mathrm{P}$ concentrations in root and leaves of $T_{1}$ and $T_{2}$ could have been due to $\mathrm{Cl}^{-}$competing for binding sites with $\mathrm{N}$ (Abdelgadir et al., 2005 ) and P (Xu et al., 2003) and/or lower $\mathrm{N}$ and $\mathrm{P}$ concentrations in the irrigation applied. The ranges of leaf $\mathrm{N}$ (9.6-13.5 $\mathrm{mg} \cdot \mathrm{g}^{-1} \mathrm{DW}$ ) reported here are similar to other reported values for confetti tree and the common spikethorn (Maytenus heterophylla) by Cramer and Bond (2013) (10-20 mg. $\left.\mathrm{g}^{-1} \mathrm{DW}\right)$. The ranges for $\mathrm{P}\left(4.4-6.5 \mathrm{mg} \cdot \mathrm{g}^{-1} \mathrm{DW}\right)$ reported here were higher than those reported by Cramer and Bond (2013) (1.1-4.2 $\left.\mathrm{mg} \cdot \mathrm{g}^{-1} \mathrm{DW}\right)$ and Aganga and Mesho (2008) (1.3 mg.g $\mathrm{g}^{-1} \mathrm{DW}$ ) for confetti tree. The increase in $\mathrm{Cl}$ and $\mathrm{Na}$ concentration in roots and leaves may be because of a low-affinity transport system for both $\mathrm{Na}$ and $\mathrm{Cl}$ as suggested by Kronzucker and Britto (2011) and Teakle and Tyerman (2010). Our results showed a higher range of leaf $\mathrm{Cl}^{-}$ (53.2-64.8 $\mathrm{mg} \cdot \mathrm{g}^{-1}$ DW) compared with those reported by Gómez-Bellot et al. (2015) in another member of

Table 4. Mean mineral composition [nitrogen $(\mathrm{N})$, phosphorous $(\mathrm{P})$, chloride $(\mathrm{Cl})$, potassium $(\mathrm{K})$, sodium $(\mathrm{Na})$, and calcium $(\mathrm{Ca})]$ in roots, stems, and leaves of confetti tree grown in $1.5-\mathrm{L}(0.40 \mathrm{gal})$ containers containing peatmoss and perlite 80:20 (by volume). Treatments consisted of a standard nutrient solution $\left(\mathrm{T}_{0}\right)$, runoff water collected from kneeholy plants irrigated with the standard nutrient solution blended 50:50 with tap water $\left(T_{1}\right)$, and 100\% runoff water collected from kneeholy plants irrigated with the standard nutrient solution $\left(\mathrm{T}_{2}\right)$.

\begin{tabular}{lcrrr}
\hline & & Roots & Stems & Leaves \\
\cline { 3 - 5 } & Irrigation treatments & & $\left(\mathbf{m g} \cdot \mathbf{g}^{-1} \mathrm{DW}\right)$ & \\
\hline $\mathrm{N}^{\mathrm{z}}$ & $\mathrm{T}_{0}$ & $13.5 \mathrm{a}^{\mathrm{y}}$ & $5.9 \mathrm{a}$ & $13.4 \mathrm{a}$ \\
& $\mathrm{T}_{1}$ & $5.8 \mathrm{~b}$ & $5.8 \mathrm{a}$ & $9.6 \mathrm{~b}$ \\
& $\mathrm{~T}_{2}$ & $5.8 \mathrm{~b}$ & $5.7 \mathrm{a}$ & $9.8 \mathrm{~b}$ \\
$\mathrm{P}$ & $\mathrm{T}_{0}$ & $6.1 \mathrm{a}$ & $4.3 \mathrm{a}$ & $6.5 \mathrm{a}$ \\
& $\mathrm{T}_{1}$ & $4.4 \mathrm{~b}$ & $4.4 \mathrm{a}$ & $4.4 \mathrm{~b}$ \\
& $\mathrm{~T}_{2}$ & $4.2 \mathrm{~b}$ & $4.6 \mathrm{a}$ & $4.6 \mathrm{~b}$ \\
$\mathrm{Cl}$ & $\mathrm{T}_{0}$ & $51.5 \mathrm{~b}$ & $60.5 \mathrm{a}$ & $53.2 \mathrm{~b}$ \\
& $\mathrm{~T}_{1}$ & $61.6 \mathrm{a}$ & $58.2 \mathrm{a}$ & $62.5 \mathrm{a}$ \\
& $\mathrm{T}_{2}$ & $61.9 \mathrm{a}$ & $59.6 \mathrm{a}$ & $64.8 \mathrm{a}$ \\
$\mathrm{K}$ & $\mathrm{T}_{0}$ & $8.6 \mathrm{a}$ & $12.0 \mathrm{a}$ & $13.6 \mathrm{a}$ \\
& $\mathrm{T}_{1}$ & $8.4 \mathrm{a}$ & $12.4 \mathrm{a}$ & $13.8 \mathrm{a}$ \\
& $\mathrm{T}_{2}$ & $8.0 \mathrm{a}$ & $12.3 \mathrm{a}$ & $13.8 \mathrm{a}$ \\
$\mathrm{Na}$ & $\mathrm{T}_{0}$ & $2.8 \mathrm{~b}$ & $3.5 \mathrm{a}$ & $2.5 \mathrm{~b}$ \\
& $\mathrm{~T}_{1}$ & $4.0 \mathrm{a}$ & $3.7 \mathrm{a}$ & $4.5 \mathrm{a}$ \\
& $\mathrm{T}_{2}$ & $4.1 \mathrm{a}$ & $3.6 \mathrm{a}$ & $4.7 \mathrm{a}$ \\
$\mathrm{Ca}$ & $\mathrm{T}_{0}$ & $4.4 \mathrm{a}$ & $6.3 \mathrm{a}$ & $5.3 \mathrm{a}$ \\
& $\mathrm{T}_{1}$ & $4.3 \mathrm{a}$ & $6.3 \mathrm{a}$ & $5.2 \mathrm{a}$ \\
& $\mathrm{T}_{2}$ & $4.2 \mathrm{a}$ & $6.4 \mathrm{a}$ & $5.2 \mathrm{a}$ \\
\hline
\end{tabular}

${ }^{\mathrm{z}} \mathrm{l} \mathrm{mg} \cdot \mathrm{g}^{-1}=1000 \mathrm{ppm}$.

${ }^{\mathrm{y}}$ Means within a column with the same letter are not significantly different at $P<0.05$ (analysis of variance and least significant difference test).

the bittersweet family (Celastraceae), dwarf japanese euonymus (10.3-13.7 $\left.\mathrm{mg} \cdot \mathrm{g}^{-1} \mathrm{DW}\right)$, suggesting confetti tree may be a hyperaccumulator of chlorine. On the other hand, the values of $\mathrm{K}\left(13.7 \mathrm{mg} \cdot \mathrm{g}^{-1} \mathrm{DW}\right)$ and $\mathrm{Ca}(5.3$ $\left.\mathrm{mg} \cdot \mathrm{g}^{-1} \mathrm{DW}\right)$ leaf concentration were lower than the values reported by Aganga and Mesho (2008) in confetti tree for $\mathrm{K}\left(15.4 \mathrm{mg} \cdot \mathrm{g}^{-1} \mathrm{DW}\right)$ and $\mathrm{Ca}$ (13.9 $\left.\mathrm{mg} \cdot \mathrm{g}^{-1} \mathrm{DW}\right)$, respectively. It is also important to highlight that the production of ornamental plants in a series irrigation system may allow for a reduction of water and nutrient inputs, but it is necessary to consider that the selection of the plants in this system is based on the different degrees of salt tolerance that exist between various species.

N U T R I E N T S O L U T I O N COMPOSITION. The addition of runoff $\left(\mathrm{T}_{1}\right.$ and $\mathrm{T}_{2}$ ) increased both the $\mathrm{pH}$ and $\mathrm{EC}$ of the nutrient solution compared with $\mathrm{T}_{0}$ (Table 5 ). The use of irrigation runoff water decreased the concentration of $\mathrm{NO}_{3}$ and $\mathrm{H}_{2} \mathrm{PO}_{4}$, but increased the concentration of $\mathrm{SO}_{4}, \mathrm{Ca}$, and $\mathrm{Mg}$, and had no significant effect on the concentration of $\mathrm{K}$ compared with $\mathrm{T}_{0}$.

The increase in $\mathrm{pH}$ in $\mathrm{T}_{1}$ and $\mathrm{T}_{2}$ compared with $T_{0}$ could be due to the nitrate uptake by the plants and the consequent release of $\mathrm{H}^{+}$(Mengel and Kirkby, 2001). The increase in EC in $T_{1}$ and $T_{2}$ compared with $T_{0}$ may have been due to the accumulation of ions $\left(\mathrm{Mg}^{2+}, \mathrm{Na}^{+}\right.$, and $\mathrm{Cl}^{-}$etc. $)$ in the runoff water (Massa et al., 2010) because of the high concentration of $\mathrm{Na}^{+}$and $\mathrm{Cl}^{-}$in the tap water and the reuse of the runoff water. Irrigation with $T_{1}$ and $T_{2}$ showed reduced $\mathrm{NO}_{3}{ }^{-}$and $\mathrm{H}_{2} \mathrm{PO}_{4}{ }^{-}$concentrations compared with $\mathrm{T}_{0}$, which is

Table 5. Average weekly values of $\mathrm{pH}$, electrical conductivity (EC), and concentrations of nutrient elements [nitrate $\left(\mathrm{NO}_{3}{ }^{-}\right)$, phosphate $\left(\mathrm{H}_{2} \mathrm{PO}_{4}{ }^{-}\right)$, chloride $\left(\mathrm{Cl}^{-}\right)$, sulphate $\left(\mathrm{SO}_{4}{ }^{2-}\right)$, calcium $\left(\mathrm{Ca}^{2+}\right)$, magnesium $\left(\mathrm{Mg}^{2+}\right)$, potassium $\left(\mathrm{K}^{+}\right)$, and sodium $\left.\left(\mathrm{Na}^{+}\right)\right]$in runoff from confetti tree grown in $1.5-\mathrm{L}(0.40 \mathrm{gal})$ containers containing peatmoss and perlite 80:20 (by volume). Treatments consisted of a standard nutrient solution $\left(\mathrm{T}_{0}\right)$, runoff water collected from kneeholy plants irrigated with the standard nutrient solution blended 50:50 with tap water $\left(T_{1}\right)$, and $100 \%$ runoff water collected from kneeholy plants irrigated with the standard nutrient solution $\left(\mathrm{T}_{2}\right)$.

\begin{tabular}{|c|c|c|c|c|c|c|c|c|c|c|}
\hline \multirow[b]{2}{*}{$\begin{array}{l}\text { Irrigation } \\
\text { treatments }\end{array}$} & \multicolumn{10}{|c|}{ Chemical parameters } \\
\hline & $\mathrm{pH}$ & $\begin{array}{c}\mathrm{EC} \\
\left(\mathrm{d} S \cdot \mathrm{m}^{-1}\right)^{\mathrm{z}} \\
\end{array}$ & $\begin{array}{c}\mathrm{NO}_{3}^{-} \\
\left(\mathrm{mg} \cdot \mathrm{L}^{-1}\right)^{z}\end{array}$ & $\begin{array}{l}\mathrm{H}_{2} \mathrm{PO}_{4}^{-} \\
\left(\mathrm{mg} \cdot \mathrm{L}^{-1}\right)\end{array}$ & $\begin{array}{c}\mathrm{Cl}^{-} \\
\left(\mathrm{mg} \cdot \mathrm{L}^{-1}\right)\end{array}$ & $\begin{array}{c}\mathrm{SO}_{4}^{2-} \\
\left(\mathrm{mg} \cdot \mathrm{L}^{-1}\right)\end{array}$ & $\begin{array}{c}\mathrm{Ca}^{2+} \\
\left(\mathrm{mg} \cdot \mathrm{L}^{-1}\right) \\
\end{array}$ & $\begin{array}{c}\mathrm{Mg}^{2+} \\
\left(\mathrm{mg} \cdot \mathrm{L}^{-1}\right)\end{array}$ & $\begin{array}{c}\mathrm{K}^{+} \\
\left(\mathrm{mg} \cdot \mathrm{L}^{-\mathbf{l}}\right)\end{array}$ & $\begin{array}{c}\mathrm{Na}^{+} \\
\left(\mathrm{mg} \cdot \mathrm{L}^{-1}\right) \\
\end{array}$ \\
\hline $\mathrm{T}_{0}$ & $6.50 \mathrm{~b}^{\mathrm{y}}$ & $1.50 \mathrm{c}$ & $372.00 \mathrm{a}$ & $67.90 \mathrm{a}$ & $122.50 \mathrm{~b}$ & $192.00 \mathrm{~b}$ & $80.00 \mathrm{~b}$ & $33.60 \mathrm{~b}$ & $117.00 \mathrm{a}$ & $59.80 \mathrm{~b}$ \\
\hline $\mathrm{T}_{1}$ & $7.40 \mathrm{a}$ & $1.89 \mathrm{~b}$ & $181.82 \mathrm{~b}$ & $2.91 \mathrm{~b}$ & $576.80 \mathrm{a}$ & $322.56 \mathrm{a}$ & $464.80 \mathrm{a}$ & $115.44 \mathrm{a}$ & $105.30 \mathrm{a}$ & $332.81 \mathrm{a}$ \\
\hline $\mathrm{T}_{2}$ & $7.20 \mathrm{a}$ & $2.47 \mathrm{a}$ & $220.10 \mathrm{~b}$ & $3.88 \mathrm{~b}$ & $613.90 \mathrm{a}$ & $339.84 \mathrm{a}$ & $518.80 \mathrm{a}$ & $133.25 \mathrm{a}$ & $119.34 \mathrm{a}$ & $369.28 \mathrm{a}$ \\
\hline
\end{tabular}

${ }^{\mathrm{z}} \mathrm{l} \mathrm{dS} \cdot \mathrm{m}^{-1}=1 \mathrm{mmho} \cdot \mathrm{cm}^{-1}, \mathrm{l} \mathrm{mg} \cdot \mathrm{L}^{-1}=1 \mathrm{ppm}$.

${ }^{\mathrm{y}}$ Means within a column with the same letter are not significantly different at $P<0.05$ (analysis of variance and least significant difference test). 
likely due to plant uptake by kneeholly.

\section{Conclusions}

Our results indicate that the production of confetti tree in containers in $T_{2}$ resulted in higher growth rates compared with $T_{1}$ and $T_{0}$. In addition, irrigation with $T_{1}$ and $T_{2}$ led to an increase of chlorophyll concentrations and consequently an increase in the green index color in leaves compared with the control. The increase in the green index color in leaves is highly valued by ornamental growers aesthetically. However, the mineral composition of roots and leaves were affected by irrigation treatments resulting in an increase of $\mathrm{Na}$ and $\mathrm{Cl}$ concentration and a decline of $\mathrm{N}$ and $\mathrm{P}$ concentration compared with the control. Results showed that the increase of growth parameters and chlorophyll concentration in relation to the highest $\mathrm{EC}$ in $\mathrm{T}_{2}$ could be due to the species salt tolerance. Based on the results presented here, and under similar water chemistry, it is feasible to reuse irrigation runoff in series and without dilution for confetti tree production in a nursery setting, without reducing plant growth. This would be particularly beneficial in locations that have water quality or water quantity issues. Additional knowledge and understanding regarding irrigation and nutrient management practices, particularly regarding the reuse of runoff water in the production of ornamental plants would be beneficial for researchers and growers in managing water resources.

\section{Literature cited}

Abdelgadir, E.M., M. Oka, and H. Fujiyama. 2005. Characteristics of nitrate uptake by plants under salinity. J. Plant Nutr. 28:33-46.

Aganga, A.A. and E.O. Mesho. 2008. Mineral contents of browse plants in Kweneng District in Botswana. Agron. J. 3:93-98.

Ali, M.M., A. Al-Ani, D. Eamus, and D.K.Y. Tan. 2012. A new image processing based technique to determine chlorophyll in plants. Amer. Eurasian J. Agr. Environ. Sci. 12:1323-1328.

Álvarez, S., M.J. Gómez-Bellot, M. Castillo, S. Bañón, and M.J. Sánchez-Blanco. 2012. Osmotic and saline effect on growth, water relations, and ion uptake and translocation in Phlomis purpurea plants. Environ. Expt. Bot. 78:138-145.
Cassaniti, C., C. Leonardi, and T.J. Flowers. 2009. The effect of sodium chloride on ornamental shrubs. Sci. Hort. 122:586-593.

Chong, C., G. Lumis, P. Purvis, and A. Dale. 2004. Growth and nutrient status of six species of nursery stock grown in a compost-based medium with recycled nutrients. HortScience 39:60-64.

Cramer, M.D. and W.J. Bond. 2013. Nfertilization does not alleviate grass competition induced reduction of growth of African savanna species. Plant Soil 366:563-574.

Csáky, A. and M.A. Martínez-Grau. 1998. Técnicas experimentales en síntesis orgánica. Editorial Síntesis, Madrid, Spain.

Gómez-Bellot, M.J., P.A. Nortes, M.F. Ortuño, M.J. Sánchez-Blanco, K. SantosGoncalves, and S. Bañón. 2014. Daily photosynthesis, water relations, and ion concentrations of euonymus irrigated with treated wastewater. HortScience 49:1292-1297.

Gómez-Bellot, M.J., M.F. Ortuño, P.A. Nortes, J. Vicente-Sánchez, S. Bañón, and M.J. Sánchez-Blanco. 2015. Mycorrhizal euonymus plants and reclaimed water: Biomass, water status and nutritional responses. Sci. Hort. 186:61-69.

Graham, G.T. 1998. Root exudates: Methods of analysis and ecological significance. Dept. Plant Agr., Hort. Sci. Div., Univ. Guelph, Tech. Note 53060001, Version 1.1.1.

Grattan, S., J. Oster, S. Benes, and S. Kaffka. 2011. Use of saline drainage waters for irrigation, p. 687-719. In: W.W. Wallender and K.K. Tanji (eds.). Agricultural salinity assessment and management. 2nd ed. Amer. Soc. Civil Eng., Reston, VA.

Hogue, E., G.E. Wilcow, and D.J. Cantliffe. 1970. Effect of soil $P$ on phosphate fraction in tomato leaves. J. Amer. Soc. Hort. Sci. 95:174-176.

Hu, H., J. Zhang, X. Sun, and X. Zhang. 2013. Estimation of leaf chlorophyll content of rice using image color analysis. Can. J. Rem. Sens. 39:185-190.

Jarecki, M.K., C. Chong, and R.P. Voroney. 2005. Evaluation of compost leachates for plant growth in hydroponic culture. J. Plant Nutr. 28:1-17.

Jimenez, R.M. and M.R. Caballero. 1990. El cultivo industrial de plantas en maceta. Editorial Horticultura Sociedad Limitada, Barcelona, Spain.

Krom, M.D. 1980. Spectrophotometric determination of ammonia: Study of a modified Berthelot reaction using salicylate and dicholoroisocyanurate. Analyst 105:305-316.
Kronzucker, H.J. and D.T. Britto. 2011. Sodium transport in plants: A critical review. New Phytol. 189:54-81.

Lachica, M., A. Aguilar, and J. Yanez. 1973. Análisis foliar: Métodos utilizados en la Estación Experimental del Zaidin. Anales de Edafología y Agrobiología 32:1033-1047.

Lopez, G. 2004. Guía de los árboles y arbustos de la Península Ibérica y Baleares. 2nd ed. Editorial Mundiprensa, Madrid, Spain.

Massa, D., L. Incrocci, R. Maggini, G. Carmassi, C.A. Campiotti, and A. Pardossi. 2010. Strategies to decrease water drainage and nitrate emission from soilless cultures of greenhouse tomato. Agr. Water Mgt. 97:971-980.

Mayotte, J.K., R. Hall, and G. Connellan. 1996. Recirculating subirrigation systems for nursery production. Comb. Proc. Intl. Plant Prop. Soc. 46:82-85.

Mengel, K. and E.A. Kirkby. 2001. Principles of plant nutrition. Kluwer Academic Publ., Dordrecht, The Netherlands.

Narváez, L., C. Cunill, R. Cáceres, and O. Marfâ. 2011. Design and monitoring of horizontal subsurface-flow constructed wetlands for treating nursery leachates. Bioresour. Technol. 102:6414-6420.

Owen, J.S., Jr., S.L. Warren, T.E. Bilderback, and J.P. Albano. 2008. Phosphorus rate, leaching fraction, and substrate influence on influent quantity, effluent nutrient content, and response of a containerized woody ornamental crop. HortScience 43:906-912.

Polomski, R.F., M.D. Taylor, D.G. Bielenberg, T. Whitwell, W.C. Bridges, and S.J. Klaine. 2008. Differential nitrogen and phosphorus recovery by five aquatic garden species in laboratoryscale subsurface constructed wetlands. HortScience 43:868-874.

Polomski, R.F., M.D. Taylor, S.A. White, S.J. Klaine, T. Whitwell, and W.C. Bridges. 2005. Greenhouse screening of landscape plants for their $\mathrm{N}$ - and $\mathrm{P}$-uptake recovery in a remediation system. Proc. Southern Nursery Assn. Res. Conf. 50:560-563.

Purvis, P., C. Chong, and G.P. Lumis. 2000. Recirculation of nutrients in container nursery production. Can. J. Plant Sci. 80:39-45.

Rana, G. and N. Katerji. 2000. Measurement and estimation of actual evapotranspiration in the field under Mediterranean climate: A review. Eur. J. Agron. 13:125153.

Rengel, Z. 1999. Mineral nutrition of crops: Fundamental mechanisms and implications. CRC Press, Boca Raton, FL. 


\section{Research Reports}

Su, N., M. Bethune, L. Mann, and A. Heuperman. 2005. Simulating water and salt movement in tile-drained fields irrigated with saline water under a serial biological concentration management scenario. Agr. Water Mgt. 78:165-180.

Teakle, N.L. and S.D. Tyerman. 2010. Mechanisms of $\mathrm{Cl}^{-}$transport contributing to salt tolerance. Plant Cell Environ. 33:566-589.
Vaesen, K., S. Gilliams, K. Nackaerts, and P. Coppin. 2001. Ground-measured spectral signatures as indicators of ground cover and leaf area index: The case of paddy rice. Field Crops Res. 69:13-25.

Veronese, G. 2014. A study on the genus Ruscus and its horticultural value. Cambridge Univ. Botanic Garden, Cambridge, UK.
Wellburn, A. 1994. The spectral determination of chlorophylls a and b, as well as total carotenoids, using various solvent with spectrophotometers of different resolution. J. Plant Physiol. 144:307-313.

$\mathrm{Xu}$, H.L., R. Wang, R.Y. Xu, M.A.U. Mridha, and S. Goyal. 2003. Yield and quality of leafy vegetables grown with organic fertilizations. Acta Hort. 627: 25-33. 